\title{
Social origin and the ability to self-evaluate school performance accurately
}

\author{
Benjamin Rosche ${ }^{1}$ \\ Department of Social Sciences, University of Mannheim, Mannheim, Germany
}

\begin{abstract}
As for students many consequential life decisions still lie ahead it is vitally important that their choices suit their abilities. Concerning education a misperception of academic ability can lead to educational misinvestment with potentially severe consequences. That is why this paper investigates if there are disparities in the ability to accurately self-evaluate school performance by social origin. To the best of the author's knowledge this is the first paper considering this important research question. In doing so, the paper has two emphases: firstly, a theoretical model, arguing why disparities in the ability to accurately self-evaluate school performance by social origin are likely, is proposed and secondly an empirical study is conducted in order to examine if disparities by social origin are findable. The key results indicate that both students with less and students with highly educated parents underestimate their school performance, if they have school grades higher than the average and overestimate their school performance, if they have school grades lower than the average. However, this relationship is intensified for students with less educated parents and therefore they self-evaluate their school performance compared to students with highly educated parents less accurately.
\end{abstract}

Keywords: accuracy of self-evaluation; veridicality; academic self-concept; educational inequality; social origin; school performance; social capital; National Educational Panel Study (NEPS)

\section{Introduction}

In modern societies the educational attainment of an individual is a crucial determinant of his or her opportunities in life. Thus one of the most important areas of sociological research focuses on inequality in educational opportunity (IEO). By now a great deal of research has demonstrated that social origin has a significant influence on both educational performance and choice (Blossfeld \& Shavit 1993; Jackson 2013). The distinction between a performance and choice effect (which in sum amount to the actual IEO) is of great importance insofar that it reveals a self-selection of students aside from a selection undertaken by the education system. Concerning choice the sociological rational-choice theory models a student's educational career as sequential investment decisions at institutional determined transition points (Erikson \& Jonsson 1996a; Breen \& Goldthorpe 1997; Esser 2002b). Since the actual consequences of these decisions are difficult to estimate, students face the risk of an expensive false investment each time. On the one hand the choice of a too low education program restricts access to high (occupational) positions in society. The choice of a too ambitious track of education on the other hand results in educational failure that costs the hitherto forgone earnings and moreover potentially increases the years of schooling (Kristen 1999: 17). It is therefore

\footnotetext{
${ }^{1}$ Corresponding author. Email: brosche@mail.uni-mannheim.de
} 
vitally important for a student to accurately estimate his or her probability of successfully finishing an education program. This estimation is primarily based on the perceived individual abilities to do so. While most researchers in this field of study have considered disparities in the individual ability between students, few have thought of differences in the students' perception of their ability (Becker 2010: 9). Some even reject the idea that social origin affects the perception of ability (Lockwood 1981; Erikson \& Jonsson 1996b). Erikson and Jonsson for instance state that they "see no reason to assume the existence of class differences in perceptions - differences in actual conditions are [...] sufficient to explain class inequalities in educational attainment" (Erikson \& Jonsson 1996b: 16). This is surprising insofar that there are good arguments both from sociological and psychological literature for assuming the existence of precisely these differences.

In the following chapter a theoretical model is exposed arguing why disparities in the ability to accurately self-evaluate school performance by social origin are likely. It is argued that due to differences in the students' social capital, students with less educated parents are less able to accurately self-evaluate their school performance compared to students with highly educated parents. Subsequently in the third chapter a brief overview of previous studies is given. In the fourth chapter the formulated hypotheses are tested with descriptive and multivariate analyses. Due to the limited scope of the paper the proposed theoretical mechanisms are not tested directly, the empirical study however indicates that students with less educated parents actually self-evaluate their school performances less accurately than students with highly educated parents. This result is summarized and discussed in the last chapter.

\section{Why could disparities in the ability to self-evaluate school performance by social origin exist?}

\section{Accurate self-evaluation}

Before addressing the question why disparities in the ability to accurately self-evaluate school performance by social origin are likely, it is necessary to define "accurate self-evaluation". A student self-evaluates his or her school-performance by comparing his or her shown school-performance (school grades for example as most common measure) to a reference norm. These frames of reference can either be internal (if the present performance is compared with earlier ones or with performances shown in other domains) or external. External frames of reference can further be distinguished into social (if the performance is compared to significant others) and objective (learning objectives for example) norms of reference (Shavelson et al. 1976; Marsh 1986; Rheinberg 2006; Dickhäuser 2006). The recurring comparison processes result in a cognitive representation of the student's ability in a certain domain - the so called (domain-specific) academic self-concept (Dickhäuser et al. 2002: 394). In his theory of social comparison processes Festinger assumes that 
human beings generally have the desire to compare their own performance with others' in order to gain accurate self-evaluations. This is especially true if objective norms of reference are not available (Festinger 1954). In his widely acknowledged theory Festinger emphasizes the importance of the social reference norm as part of the external frame of reference. Following him the present paper therefore focuses solely on external comparison processes although both internal and external frames of references are essential to get an exhaustive conception of a student's academic selfconcept. Thus an overestimated (underestimated) cognitive representation of ability is present if the student's academic self-concept outreaches (falls behind) his or her school performance in reference to the social and objective norm of reference. It is to expect that especially school classes serve as social norms of reference. Furthermore it is assumed that the objective reference norm is set by school-given learning objectives. A student then accurately self-evaluates his or her school performance when the developed academic self-concept is as high as the school performance in reference to the mates and the learning objectives.

\section{The influence of social capital: information}

In addition to their own experience students can draw inferences about the accurate level of their academic self-concept with the help of external feedback. Especially feedback given by significant others can be valued as reliable because the strong relationship and the resemblance make an accurate evaluation by significant others more likely. This resource of information can be regarded as the student's social capital (Stocké et al. 2011: 108). In recent decades the social capital framework has received substantial attention in sociology and is considered to be particularly important for educational success (Coleman 1988; Erikson \& Jonsson 1996b; Hofferth et al. 1998; Lin 2001). In the following this paper focuses on the role of social capital within the family (particularly the parentchild-relation) in the self-concept formation process and demonstrates that less educated ${ }^{2}$ parents (in reference to highly educated parents) give their children considerable less feedback about the accuracy of their academic self-concept. In addition to that they are also less able to do this accurately. These students' source of information is therefore less profitable.

Sociological approaches explaining IEO have emphasized the role of class-specific norms and values (Hyman 1966; Sewell et al. 1970; Gambetta 1987) and the motive for status maintenance (Erikson \& Jonsson 1996b; Esser 2002a) to explain the educational orientation of parents. In the following paragraphs it is argued that disparities in the parental educational orientation by social origin influence the quantity and quality of their feedback:

In the context of self-concept formation it can be assumed that less educated parents less often give their children feedback about their academic abilities because they focus less on education and

\footnotetext{
${ }^{2}$ The theoretical part of the paper focuses on education as one indicator of social origin. The same mechanisms are expected to work for other measures of social origin such as occupational prestige or income. Empirically both education and social class are used to analyze the influence of social origin.
} 
education-related abilities than highly educated parents. This mechanism can operate in a variety of ways: Less educated parents may just not think of the possibility to explicitly offer their children evaluations of their academic abilities. Further, they invest less time in school-related activities, such as helping them with their homework (Sayer et al. 2004). Thereby they create fewer possibilities to give their children feedback about their school performances implicitly. Less education-related interaction between the student and his or her parents then results in a lack of (additional) information about how the own academic abilities are to be evaluated.

According to Paulus and Blossfeld, class-specific norms and values are also important because they constrain the search for information. For less educated parents this may lead to them blinding out the benefits of higher education (Paulus \& Blossfeld 2007: 492). Thus - again in the context of selfconcept formation - it is likely that less educated parents do not only give their children considerable less feedback about their academic self-concept, but are also less able to do so due to a lack of information about the prevailing frames of reference. Less educated parents have stayed in school considerable shorter than highly educated ones. This has given them less opportunity to recognize important learning objectives. They also participate fewer in parent-teacher conferences, have fewer direct conversations with their children's teachers and exchange less often with other parents about education-related issues (Carbonaro 1998; Epstein 2011; Lareau 1987, 2011; Ream \& Palardy 2008). This behaviour does not only result in a lack of information about prevailing learning objectives, but it also blurs the parents' power to judge their children's school performance in reference to their children's mates. Less educated parents thus have difficulties in accurately evaluating their children's abilities. This seems to be an important (but rarely explained) disadvantage in additon to the often mentioned point that they have less "(tacit) knowledge about the school system" (see for example Erikson \& Jonsson 1996b: 22; Roth et al. 2010: 183). This lack of information does not only result in inaccurate feedback. Beyond that it further reduces the feedback given to the students, because their parents just do not know what to say.

In order to sum up, it can be said that students with less educated parents have considerable less informational social capital, which is expected to deteriorate the accuracy of their academic selfconcept in comparison to students with highly educated parents.

\section{The influence of social capital: orientation}

The student's social capital does not only influence his or her self-evaluation through information. The parental educational orientation as part of a student's social capital also determines his or her educational orientation which in turn influences the self-evaluation process.

The structural symbolic interactionism approach connects the (psychological) construct of "selfconcept" with the (sociological) concept of "role". It conceives the structure of the self-concept as a "hierachical organization of the idividual's role-identities" (Gecas 1982: 14) and assumes that the 
greater the commitment to a role the more important it is as part of the individual's social identity (Stryker 2002). Turner dealing with the identity commitment process - reasons that individuals merge a role into social identity if significant others identify them by it (Turner 1978: 13).

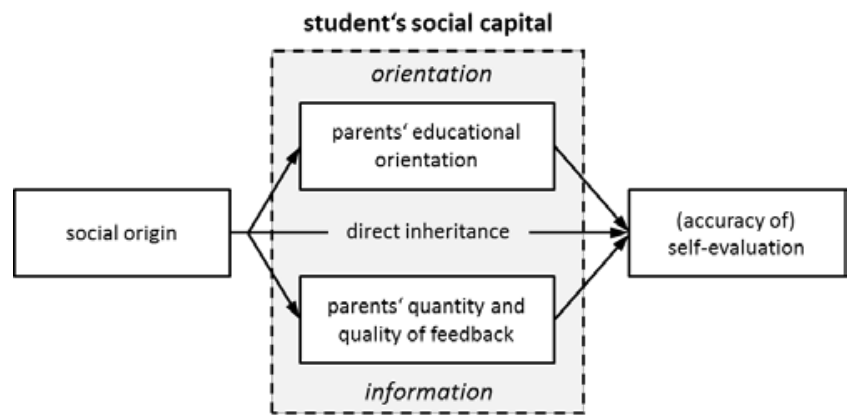

Figure 1: Graphical summary of the theoretical model. Reconsidering the aforementioned disparity in the parents' appraisal of norms and values regarding education, it has to be assumed that the centrality of the academic self-concept as part of a student's social identity should vary by social class. Students with less educated parents should devalue the academic self-concept as a role of their social identity compared to students with highly educated parents. Therefore the former should have less interest in accurately self-evaluating their academic abilities and thereby constrain their own search of information for academic self-evaluation. It is expected that this also deteriorates the accuracy of their academic self-concept in comparison with students of highly educated parents. Taken together the previous sections it is expected that

$\mathrm{H}_{1}$ : Students with less educated parents self-evaluate their school performances less accurately than students with highly educated parents (accuracy of academic self-concept).

Beyond that a direct influence of social class on variables such as self-esteem, self-efficacy and selfconcept was observed repeatedly. In a meta-analysis Twenge and Campbell found the socioeconomic status of the parents positively influencing the self-esteem of their child. In line with sociological theory such as the salience model (Rosenberg \& Pearlin 1978; Demo \& Savin-Williams 1983 ) or the theory of reflected appraisal (Cooley 1902; Mead 1934) the effect is small for primary school pupils and increases with age (Twenge \& Campbell 2002). In the context of self-concept formation it further can be expected that less educated parents hand down a low general selfconcept to their children which is negatively affecting their children's academic self-concept. Therefore it is expected that

$\mathrm{H}_{2}$ : Independently of school grades students with less educated parents self-evaluate their school performance lower than students with highly educated parents (level of academic self-concept).

\section{School performance and self-evaluation}

Beside a drive for self-assessment and consistency (Festinger 1954, 1962) psychological and sociological literature has stressed the importance of self-worth as motivation of individuals (Covington \& Beery 1976; Covington 1984; Lindenberg 1984; Ormel et al. 1999; Esser 2002a). Psychological literature has identified various strategies of individuals to protect their self-concept 
from being devalued (Helmke 1992). Cognitive attribution theories for instance state that students tend to attribute good school performance to their ability while bad school performance is attributed to a lack of effort (Weiner 1972, 1974; Covington 1984). For that reason it has to be assumed that poor performing students should be motivated to attribute their performance to a lack of effort in order to protect their academic self-concept (which is based on their assumed ability). This should deteriorate the accuracy of their academic self-concept. Good performing students in contrast should self-evaluate their academic ability more accurately. Therefore it is expected that

$\mathrm{H}_{3}$ : Poor performing students overestimate their abilities and therefore self-evaluate their school performances less accurately than good performing students (accuracy of academic self-concept).

\section{Previous research results}

The ability to accurately self-evaluate abilities and other personal attributes, also named veridicality, as a field of study has been pursued by different research traditions. Social and developmental psychologists analyze it in reference to self-concept formation (Helmke 1992) and within attribution research (Kelley 1973). Pedagogical psychologists consider disparities in veridicality by gender and its genesis (Dickhäuser \& Stiensmeier-Pelster 2003; Schilling et al. 2006). Dickhäuser \& StiensmeierPelster (2003) for instance show that female students have a lower self-concept of their mathematical ability than male ones with equal mathematical achievement and thus confirming the gender hypothesis. Clinical psychologists investigate the connection between veridicality and depression (Taylor \& Brown 1988; Försterling \& Binser 2002). Although this result has been criticized, clinical psychologists repeatedly reported that depressive students - showing a more accurate selfevaluation of their school performance - are "sadder but wiser" (Alloy \& Abramson 1979; Haaga \& Beck 1995; for a critical review: Försterling \& Binser 2002). In sociology veridicality was touched by symbolic interactionists in reference to social-structural influences on the self-concept (Gecas 1982). Though some topics were studied quite intensively, extensive efforts are rather limited so far. By now, there has been no research on the influence of social origin on the ability to accurately selfevaluate school performance. 


\section{Data, operationalization and methods}

\section{Data}

The basis of the analyses is data from the German National Educational Panel Study (NEPS) ${ }^{3}$. The used fourth starting cohort consists of representatively selected 9th grade students of all secondary education tracks in Germany surveyed in 2010/11. The data-set was chosen because both grade and academic self-concept in German and Mathematics are available. This was necessary to construct the dependent variable. The used sample consists of $\mathrm{N}=8150$ observations maximum.

\section{Accuracy of self-evaluation}

To set the student's school performance in reference to the performance of his or her mates (social reference norm) the school grade in a domain was z-standardized in reference to the mean and standard deviation of the respective class ${ }^{4}$. The same procedure was applied to the student's domain-specific academic self-concept ${ }^{5}$. In order to assess if a student's self-evaluation is accurate these two variables were then set in reference, so that:

$$
\begin{array}{r}
\text { accuracy of self-evaluation }_{i}=\text { domain-specific academic self-concept }_{i}-\text { school }_{\text {grade }} \\
\text { with } \mathrm{i}=\text { German, Mathematics }
\end{array}
$$

Values $<0$ imply an underestimation, values $>0$ an overestimation and values $=0$ (and in the proximity of 0 ) an accurate self-evaluation. The index was built for the subjects German and Mathematics separately and then arithmetically averaged. An overview of the means and standard deviations of all these variables is given in the appendix. Note that the constructed index also depends on the objective norm of reference as both school grades and academic self-concept are rated by teachers and students in reference to school-given learning objectives. The underlying assumption is that the average performance in class meets the average requirements of the learning objectives. However any forms of internal reference frames are not included in this construct. Thus observed under- and overestimations can partly be artificial because the self-evaluation of a student may be accurate in reference to past performances or performances in other domains.

\footnotetext{
${ }^{3}$ This paper uses data from the National Educational Panel Study (NEPS): Starting Cohort 4 - 9th Grade, doi:10.5157/NEPS:SC4:1.1.0. The NEPS data collection is part of the Framework Program for the Promotion of Empirical Educational Research, funded by the German Federal Ministry of Education and Research and supported by the Federal States. For more information see Blossfeld et al. (2011).

${ }^{4}$ In classes where the number of observed cases was smaller than 15 (which in many federal states roughly correspond to the minimum class size) all students of the respective school were set as reference point for mean and standard deviation. In some schools even this number of observations fell below of 15 . In these instances the type of school was set as reference point.

5 Each domain-specific academic self-concept is an arithmetically averaged index out of three items. Concerning German the students were asked if they regard themselves as a hopeless case, how fast they think to learn and how they judge their grades in this domain. Regarding Mathematics the students were asked to which degree they consent that they have always been good in this domain, how fast they think to learn in this domain and if Mathematics is one of their best subjects. For further information see Wohlkinger et al. (2011: 161f.).
} 


\section{Independent variables}

The construct of interest - social origin - was measured twofold: on the one hand the highest obtained education certificate of both parents was used as indicator and on the other hand, following the method of Relikowski et al. (2010: 151), a reduced version of the EGP classification scheme was constructed in order to measure the highest social class that both parents belong to. Since the results, which are achieved when using social class as indicator of social origin, are similar but inferior to those, which are achieved when using education, the models using social class as independent variable are expelled to the appendix. Beyond that as necessary considered and therefore used control variables are: the student's age, sex, school grades (both domains averaged and reversed scale ${ }^{6}$ ), type of school, as well as if both parents live in the household, the overall house-hold size and the respondent parent's sex. Age, school grades and the overall house-hold size were z-standardized while sex, type of school, partner status and respondent parent's sex are (categorical) dummy variables.

\section{Method}

Several multivariate linear regression models were estimated adopting two approaches: first the arithmetically averaged academic self-concept in German and Mathematics and second the accuracy of self-evaluation was used as dependent variable in order to estimate the influence of the independent variables. Concerning social origin both approaches estimate similar $\beta$-coefficients but the interpretation of the results of the former method is more straight-forward. From a theoretical perspective both school grades and academic self-concept should be conceived as ordinal variables. Methodologically the constructed dependent variables (especially the accuracy of self-evaluation) are of a metric nature as both variables approximate a continuous range of values. Due to the data structure robust standard errors having each school as cluster are used. In this way potentially correlated error terms within the schools are considered and only independence between the schools has to be ensured.

\section{Empirical results}

The following sections present the results of the empirical study. First the distribution of the accuracy of self-evaluation and differences in the mean accuracy of self-evaluation by social origin are shown. Second odds-ratios are presented to indicate disparity by social origin in the chance to accurately self-evaluate (respectively under- and overestimate) school performance. Finally multivariate analyses reveal if these findings still hold under an extensive set of control variables.

\footnotetext{
${ }^{6}$ The standardized school grades in German and Mathematics were averaged in order to append school grades as one control variable. Thus school grades are only quasi-standardized having a mean of zero and standard deviation of 0.814 . Beyond that in order to facilitate interpretation the original scale was reversed.
} 


\subsection{Descriptive results}

Looking at figure 2 it is apparent that the accuracy of self-evaluation is approximately normally distributed over the students. Table 1 presents the mean accuracy of self-evaluation for each level of parental education. Students with less educated parents seem to slightly overestimate and students with highly educated parents seem to slightly underestimate their school performance.

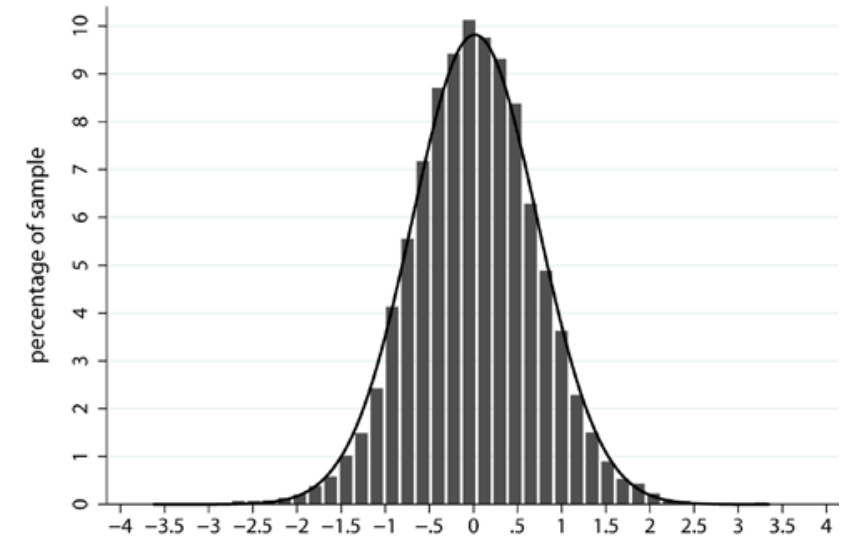

accuracy of self-evaluation

Figure 2: The univariate distribution of the constructed dependent variable: accuracy of self-evaluation.

Additionally the means indicate that students of less educated parents self-evaluate their school performance less accurately because their arithmetical average is further apart from zero and their standard deviation is the largest. T-tests indicate that both the means of students with less and highly educated parents deviate from zero statistically highly significant. Further t-tests prove that the arithmetical average of students with less educated parents exceeds the one of students with highly educated parents significantly.

\begin{tabular}{lcccccc}
\hline $\begin{array}{l}\text { accuracy of self- } \\
\text { evaluation }\end{array}$ & $\mathbf{N}$ & mean & $\begin{array}{c}\text { standard } \\
\text { deviation }\end{array}$ & standard error & \multicolumn{2}{c}{$\begin{array}{c}\text { 95\% confidence interval } \\
\text { lower }\end{array}$} \\
\hline overall $^{7}$ & 7388 & 0.015 & 0.708 & 0.008 & -0.001 & 0.031 \\
low education & 1391 & 0.074 & 0.757 & 0.020 & 0.034 & 0.114 \\
middle education & 3759 & 0.017 & 0.704 & 0.011 & -0.006 & 0.039 \\
high education & 1980 & -0.031 & 0.674 & 0.015 & -0.061 & -0.001 \\
\hline
\end{tabular}

Table 1: mean accuracy of self-evaluation by social origin. A t-test having equal means of students with low and students high education as $H_{0}$ has to be rejected at $p<0.000$. The same applies to both means equaling zero as $H_{0}(p<0.000$ for students with less educated parents; $p<0.020$ for students with highly educated parents).

Examining figure 3 it is possible to further elaborate this relationship with the aid of odds-ratios. This odds-ratios help to answer the question if students with less educated parents underestimate / accurately self-valuate / overestimate their school performance compared to students with highly educated parents. Regarding values from -0.5 to 0.5 points on the accuracy of self-evaluation scale as accurate (roughly $50 \%$ of the sample) it can be seen that students with less educated parents compared to students with highly educated parents have just four fifth the chance to underestimate and 1.3 times the chance to overestimate their school performance. When relaxing the condition of

\footnotetext{
${ }^{7}$ As both the self-concept and the school grades are standardized they have a mean of zero and a standard deviation of one. Accordingly the accuracy of self-evaluation as their difference exhibits a mean of zero. However, the standard deviation is smaller than one as the covariance of self-concept and grades is positive and $\operatorname{Var}(\mathrm{X}-\mathrm{Y})=\operatorname{Var}(\mathrm{X})+\operatorname{Var}(\mathrm{Y})-\mathbf{2} \operatorname{Cov}(\mathbf{X}, \mathbf{Y})$. In addition to that the accuracy of self-evaluation in German and Mathematics was averaged. As a result of all this it is only quasi-standardized. Actually also the overall mean of the accuracy of self-evaluation differs slightly from zero as some observations missing either only grade or self-concept were considered in the standardization but lead to a missing in the accuracy of selfevaluation.
} 
accuracy to -1.5 to 1.5 points apart from zero and thus labeling roughly $95 \%$ of the students as accurately self-evaluating, the odds-ratios are even more pronounced: students with less educated parents now face roughly half the chance to accurately self-evaluate their school performance and have two times the chance to overestimate themselves compared to students with highly educated parents. They now also have a higher chance to underestimate their school performance. However the actual effect sizes should not be overrated as Cramer's $V$ reveals only a minor relationship $(V=0.06)$ albeit significantly $(p<0.01)$ deviating from statistical independence $\left(\chi^{2}\right.$-Test).

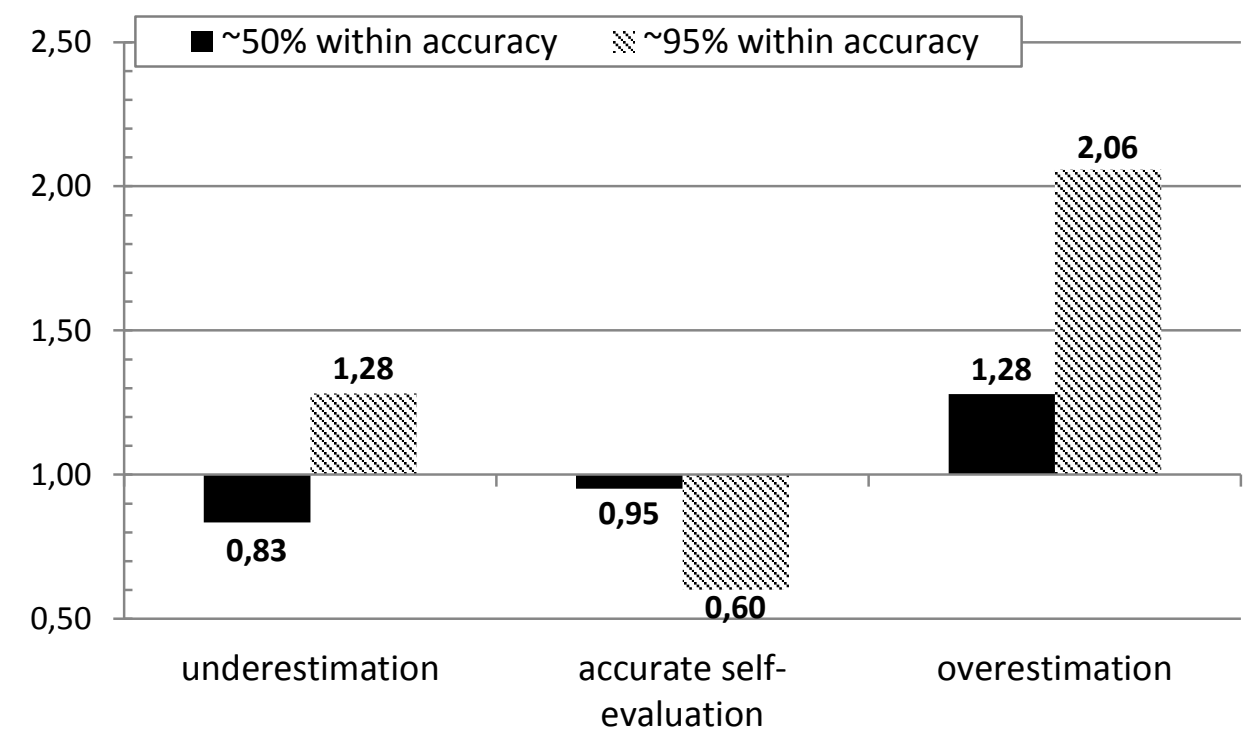

Figure 3: These odds-ratios indicate if students with less educated parents underestimate / accurately self-valuate / overestimate their school performance compared to students with highly educated parents. The consistent black bars present odds-ratios regarding values between -0.5 and 0.5 points on the self-evaluation scale as accurate self-evaluation (equaling $50 \%$ of the observations). The dashed black bars show odds-ratios having a relaxed definition of accuracy considering values between -1.5 and 1.5 points as accurate self-evaluation (roughly $95 \%$ of the observations).

Taken together the descriptive findings suggest that students with less educated parents selfevaluate their school performance less accurately which is in line with the first hypothesis. In addition to that the presented evidence predominantly indicates an overestimation of school performance by students with less educated parents that contradicts the second hypothesis that they underestimate their school performance. However, as differences in grades were not considered so far, it can be assumed that this relationship is only found due to the stronger motivation of poor performing students to protect their self-worth and the circumstance that students with less educated parents have inferior grades (see appendix).

\subsection{Multivariate results}

Table 2 presents four linear regression models, which estimate the academic self-concept (model 1) and the accuracy of self-evaluation (model 2) of a student. Since the effects of the independent on the two different dependent variables are much the same, just the main difference is highlighted: Unsurprisingly school grades have an overwhelming positive effect on the academic self-concept of a student. Figure 4 illustrates this relationship: the better the school grades the higher the academic 
self-concept and vice versa ${ }^{8}$. When estimating the accuracy of self-evaluation by contrast the $\beta$ coefficient of school grades becomes negative. While average school grades go together with an accurate self-evaluation the negative $\beta$-coefficient reveals, that students with school grades higher than average underestimate their school performance whereas students with school grades lower than average overestimate their school performance. As quadratic school grades are also significant, this relationship weakens for school grades above the mean and strengthens for school grades below the mean. Figure 5 illustrates these results.

\begin{tabular}{|c|c|c|c|c|}
\hline & \multicolumn{2}{|c|}{$\begin{array}{l}\text { quasi-standardized } \\
\text { academic self-concept }\end{array}$} & \multicolumn{2}{|c|}{$\begin{array}{c}\text { quasi-standardized accuracy } \\
\text { of self-evaluation }\end{array}$} \\
\hline & null model & model 1 & null model & model 2 \\
\hline School grades & $\begin{array}{c}0.444^{* * *} \\
(0.015)\end{array}$ & $\begin{array}{c}0.489 * * * \\
(0.020)\end{array}$ & $\begin{array}{c}-0.553^{* * *} \\
(0.015)\end{array}$ & $\begin{array}{c}-0.511 * * * \\
(0.020)\end{array}$ \\
\hline$(\text { School grades })^{2}$ & $\begin{array}{l}0.0243^{*} \\
(0.010)\end{array}$ & $\begin{array}{c}0.0178+ \\
(0.010)\end{array}$ & $\begin{array}{l}0.0266^{*} \\
(0.010)\end{array}$ & $\begin{array}{l}0.0205^{*} \\
(0.010)\end{array}$ \\
\hline Migration background & $\begin{array}{c}0.00691 \\
(0.027)\end{array}$ & $\begin{array}{c}0.00590 \\
(0.027)\end{array}$ & $\begin{array}{l}0.0193 \\
(0.027)\end{array}$ & $\begin{array}{l}0.0183 \\
(0.027)\end{array}$ \\
\hline Female & $\begin{array}{c}-0.147^{* * *} \\
(0.015)\end{array}$ & $\begin{array}{c}-0.148^{* * *} \\
(0.014)\end{array}$ & $\begin{array}{c}-0.147^{* * *} \\
(0.015)\end{array}$ & $\begin{array}{c}-0.148^{* * *} \\
(0.014)\end{array}$ \\
\hline Female * School grades & $\begin{array}{c}0.0627^{* * *} \\
(0.018)\end{array}$ & $\begin{array}{c}0.0641^{* * *} \\
(0.018)\end{array}$ & $\begin{array}{c}0.0616^{* * *} \\
(0.018)\end{array}$ & $\begin{array}{c}0.0627^{* * *} \\
(0.018)\end{array}$ \\
\hline Low education & & $\begin{array}{c}-0.0637^{*} \\
(0.026)\end{array}$ & & $\begin{array}{c}-0.0636^{*} \\
(0.025)\end{array}$ \\
\hline Middle education & & $\begin{array}{c}-0.0349 \dagger \\
(0.018)\end{array}$ & & $\begin{array}{c}-0.0390^{*} \\
(0.018)\end{array}$ \\
\hline Low education * School grades & & $\begin{array}{c}-0.152^{* * *} \\
(0.030)\end{array}$ & & $\begin{array}{c}-0.141 * * * \\
(0.029)\end{array}$ \\
\hline Middle education * School grades & & $\begin{array}{c}-0.0459^{*} \\
(0.021)\end{array}$ & & $\begin{array}{c}-0.0439 * \\
(0.021)\end{array}$ \\
\hline Constant & $\begin{array}{c}0.103 \\
(0.072) \\
\end{array}$ & $\begin{array}{c}0.119 \\
(0.072) \\
\end{array}$ & $\begin{array}{c}0.117 \\
(0.072) \\
\end{array}$ & $\begin{array}{l}0.135 \dagger \\
(0.072) \\
\end{array}$ \\
\hline$N$ & 5881 & 5881 & 5881 & 5881 \\
\hline$R^{2}$ & 0.324 & 0.328 & 0.392 & 0.395 \\
\hline $\bar{R}^{2}$ & 0.322 & 0.326 & 0.390 & 0.393 \\
\hline
\end{tabular}

Table 2: Four linear regression models with academic self-concept (model 1) and accuracy of self-evaluation (model 2) as dependent variable. Note that school grades are quasi-standardized (see footnote 6) and the reference category for parental education is high education. Also controlled for: age, school type, both parents living in the household, household, overall household size, and sex of respondent parent. Robust standard errors in parentheses. $+p<0.10, * p<$ $0.05, * * p<0.01, * * * p<0.001$. Source: NEPS, SC4.

\footnotetext{
${ }^{8}$ To be able to illustrate the findings graphically some independent variables had to hold constant. This and all following figures refer to a male high school student of average age with no migration background living with both parents in a household of average size and having the mother completed the questionnaire.

${ }^{9}$ To only have one dependent variable measuring the academic self-concept, the standardized academic selfconcepts in German and Mathematics are averaged. Thus academic self-concept is only quasi-standardized having a mean of zero and standard deviation of 0.68 . The same imprecision applies to accuracy of selfevaluation (see footnote 8) and school grades (see footnote 7).
} 


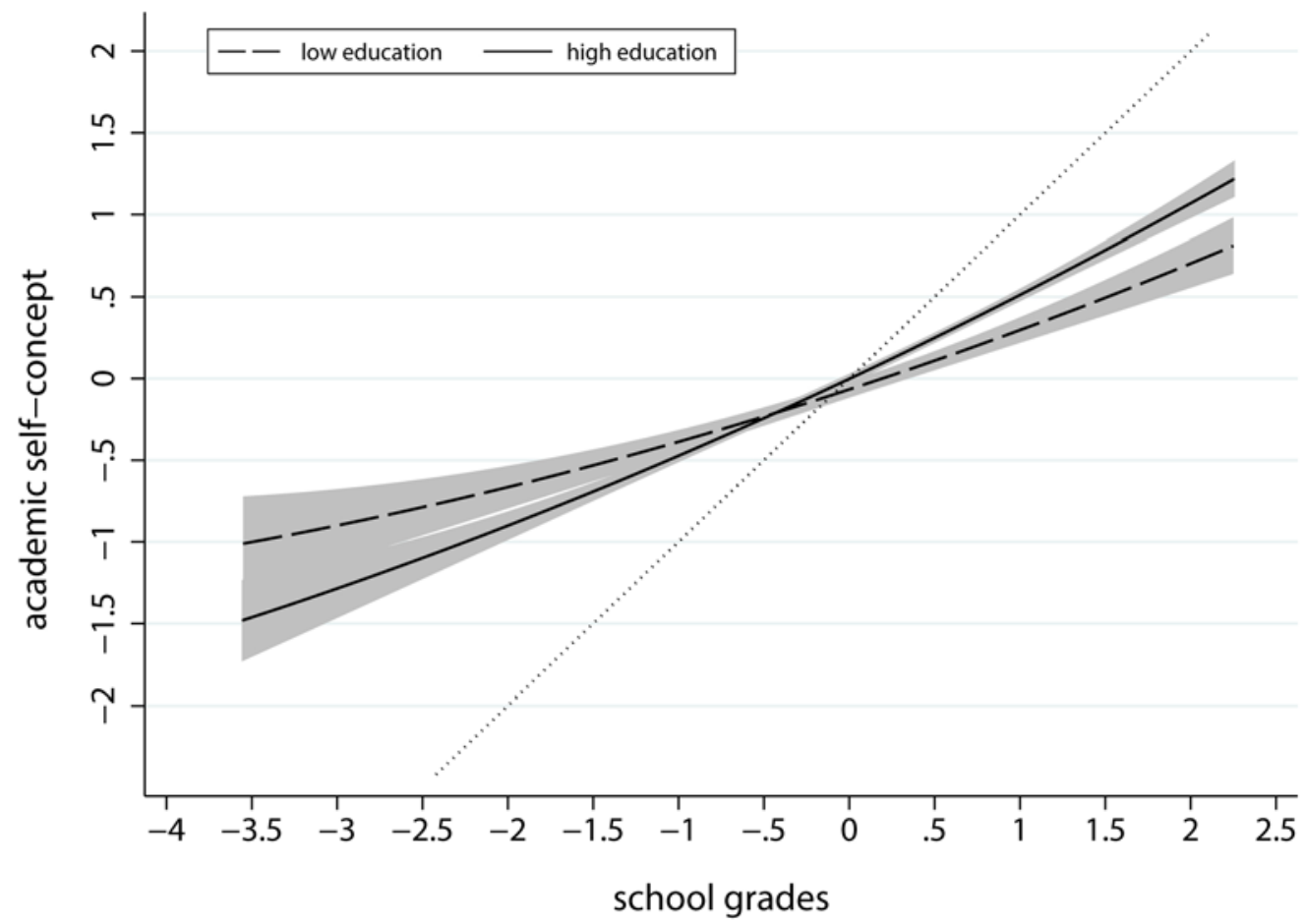

Figure 4: Bivariate relationship between quasi-standardized school grades and quasi-standardized academic self-concept by educational background of the students' parents. The dotted line signifies a perfect accurate self-evaluation. The gray areas at the estimated functions show the confidence regions. Some variables are held constant, see footnote 8.

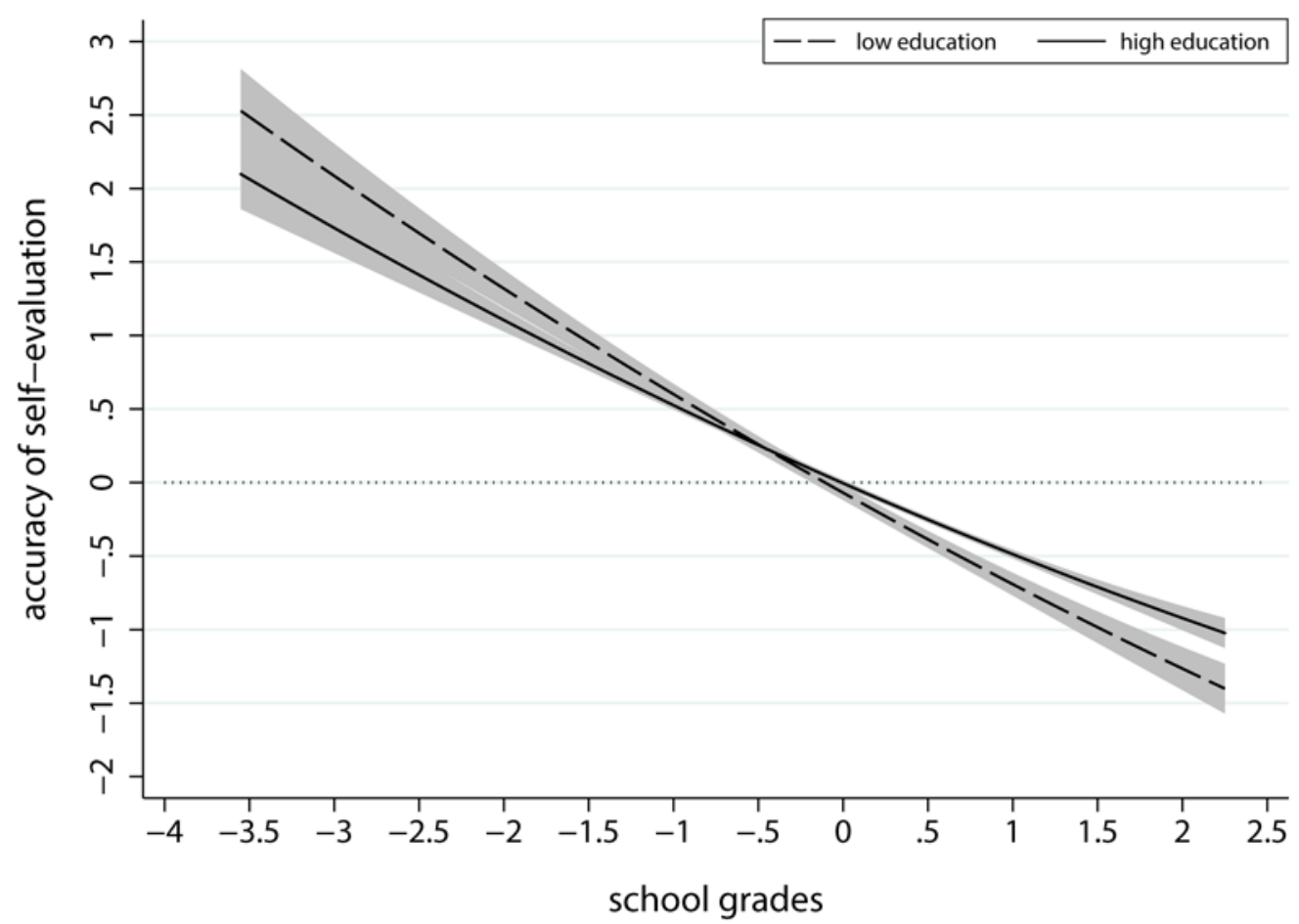

Figure 5: Bivariate relationship between quasi-standardized school grades and quasi-standardized accuracy of self-evaluation by educational background of the students' parents. The dotted line signifies a perfect accurate self-evaluation. The gray areas at the estimated functions show the confidence regions. Some variables are held constant, see footnote 8. 
Thus on the basis of this evidence the third hypothesis can partly be confirmed: Poor performing students actually tend to overestimate their school performance. However the expectation that poor performing students self-evaluate their school performance less accurately has to be rejected: Good performing students tend to underestimate their school grades and therefore also inaccurately selfevaluate their school performance.In order to examine the influence of social origin on the accuracy of self-evaluation, model 2 , which is directly estimating this relationship, is discussed. With an adjusted $R^{2}$ of 39.0 the null model reveals a good adjustment to the data. Parental education as measure of social origin exhibits a significant effect under the extensive set of control variables. The $\beta$-coefficient indicates that having less (or middle) educated parents compared to highly educated ones has a negative influence on the accuracy of self-evaluation. This means that students with less and middle educated parents overestimate their school performance less likely albeit the effect size is marginal. However, the interaction of school grades with parental education is also statistically highly significant revealing a considerable larger effect size. This interaction implies that the mentioned general relationship between school grades and self-evaluation is intensified for students with less (and middle) educated parents. While the differences in the perception between these three groups are marginal for average school grades, they increase if students achieve school grades more apart from the mean. Though both poor performing students with less and poor performing students with highly educated parents overestimate themselves, a student with less educated parents and school grades three points lower than the average for instance has a by 0.36 points less accurate (higher) self-evaluation than a student with highly educated parents and the same school grades. As the school grades in this example are held constant, this difference equals the difference in the quasi-standardized academic self-concept ${ }^{10}$. Reconverted to the original scale of the academic self-concept ranging from one to four, in this example the student with less educated parents shows an academic self-concept of 2.05 while the student with highly educated parents only exhibits an academic self-concept of $1.76^{11}$. By contrast a student with less educated parents, who has school grades two points above the average, develops an academic self-concept (again ranging from one to four) that is 0.28 points lower than the one of a student with highly educated parents and the same school grades. These estimations reveal no huge disparities by far. However the effect size of low

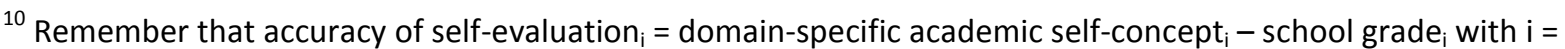
German, Mathematics.

${ }^{11}$ In these examples the same independent variables as in figure 4 and 5 are held constant. For the student with less educated parents an accuracy of self-evaluation equaling 2.15 and for the student with highly educated parents, an accuracy of self-evaluation equaling 1.79 is estimated. As the quasi-standardized academic self-concept has a standard deviation of 0.68 the standardized academic self-concept of the student with less educated parents in the example is $\frac{2.15-3}{0.68}=-1.25$ standard deviations above the mean. The actual mean and standard deviation of the academic self-concept is 2.74 and 0.55 . Thus his or her actual academic self-concept amounts to $-1.25 * 0.55+2.74=2.05$. The actual academic self-concept of the student with highly educated parents can be calculated the same way: $\frac{1.79-3}{0.68}=-1.78$ and $-1.78 * 0.55+2.74=1.76$.
} 
parental education is comparable and for most ranges of school grades even greater than the effect of the student's sex, which in these models is also significant. In line with studies in pedagogical psychology the models show that female students tend to underestimate their school performance. Therefore the effect of social origin - although relatively small - is comparable to the frequently discussed gender effect. The f-test of the unrestricted model is highly significant $(p<0.0001)$ albeit the explanatory power only increases by 0.3 percent. Considering the confidence intervals in figure 5 it is apparent that for school grades lower than the average the confidence intervals slightly overlap as the confidence region is relatively large. When having school grades higher than the average on the other hand, the disparities in the accuracy of self-evaluation by social origin can clearly be distinguished. In any case students with less educated parents self-evaluate their school performance less accurately. Figure 5 shows that the distance between the dashed line measuring the accuracy of students with less educated parents and the dotted (accuracy) reference line is throughout larger than the distance between the solid line measuring the accuracy of students with highly educated parents and the dotted (accuracy) reference line.

Therefore - in line with the descriptive results - on the basis of the presented models the first hypotheses that students with less educated parents self-evaluate school performance less accurately can be confirmed. The second hypothesis that students with less educated parents underestimate their school performance can neither be confirmed nor rejected. Instead the relationship has to be specified more precisely: students with less educated parents underestimate their school performance having school grades higher than the average and overestimate their school performance having school grades lower than the average. Although this is also true for students with highly educated parents the relationship is intensified for students with less educated ones.

\section{Conclusion and discussion}

As for students many consequential life decisions still lie ahead it is vitally important that their choices suit their abilities. Concerning education a misperception of academic ability can lead to educational misinvestment with potentially severe consequences. Therefore this paper investigated, if social origin influences the ability to accurately self-evaluate school performance. To the best of the author's knowledge this is the first paper considering this important research question. In doing so, the paper had two emphases: firstly, a theoretical model, arguing why disparities in the ability to accurately self-evaluate school performance by social origin are likely, is proposed and secondly an empirical study was conducted in order to examine if disparities by social origin are findable. Due to the limited scope of the paper the proposed theoretical mechanisms could not be tested directly. 
Using data from the National Educational Panel Study (NEPS) it was investigated if the academic selfconcept of 9th grade students in Germany is as high as their school performance in reference to their mates and given learning objectives. Then, with the aid of multivariate linear regression models, it was examined if the students' social origin influences the accuracy of this self-evaluation process. The key results indicate that both students with less and students with highly educated parents underestimate their school performance, if they have school grades higher than the average and overestimate their school performance, if they have school grades lower than the average. However, this relationship is intensified for students with less educated parents and therefore they selfevaluate their school performance compared to students with highly educated parents less accurately. The effect size is relatively small but highly significant. Besides in the models the impact is comparable to the effect of the student's sex. Therefore the effect of social origin - although relatively small - is similar to the frequently discussed gender effect. Moreover also small differences in the perception of performance should not be underrated because they influence both the students' behaviour and the behaviour of others like their teachers', who react on the students' selfconcept, in the long term.

The major limitation of the study is that the underlying mechanisms of these findings could not be uncovered yet. Therefore further research not only should try to replicate the results, but also test if the students' social capital mediates the relationship between social origin and the accuracy of selfevaluation. As argued in the theoretical part, this seems likely. Beyond that, the as accurate defined self-evaluation can partly be artificial because it is constructed in reference to social and objective norms of reference only. Any other forms of internal reference are ignored completely. Thus observed under- and overestimations of school performance may actually be accurate when comparing them to past performances or performances in other domains. However especially the found interaction between school grades and social origin indicates that - regardless if accurate or not - the perception of school performance differs by social origin. However further research aiming at defining accuracy of self-evaluation scientifically more precise should also consider internal frames as reference points. Försterling \& Binser (2002) have described an approach which could be appropriate to do this.

Nevertheless this paper contributes to the field of research studying the genesis of inequality in educational opportunity (IEO) by revealing that disparities in the ability to self-evaluate school performance by social origin do exist. Potentially these disparities are a further mechanism explaining IEO.

\section{References}

Alloy, L.B. \& L.Y. Abramson, 1979: Judgment of contingency in depressed and nondepressed students: Sadder but wiser? Journal of Experimental Psychology: General 108: 441-485. 
Bäumer, T., N. Preis, H.-G. Roßbach, L. Stecher \& E. Klieme, 2011: 6 Education processes in lifecourse-specific learning environments. Zeitschrift für Erziehungswissenschaft Special Issue 14: 87-101.

Becker, B., 2010: Bildungsaspiration von Migranten. Determinanten und Umsetzung in Bildungsergebnisse. Mannheimer Zentrum für Europäische Sozialforschung (MZES).

Blossfeld, H.-P., H.G. Rossbach \& J. von Maurice, 2011: Education as a lifelong process. The German National Educational Panel Study (NEPS). Zeitschrift für Erziehungswissenschaft Special Issue 14.

Blossfeld, H.-P. \& Y. Shavit (Hrsg.), 1993: Persisting Barriers. Changing Educational Attaintment in Thirteen Countries. Boulder: Westview Press.

Breen, R. \& J.H. Goldthorpe, 1997: Explaining Educational Differentials. Towards a Formal Rational Action Theory. Rationality and Society 9: 275-305.

Carbonaro, W.J., 1998: A Little Help from My Friend's Parents: Intergenerational Closure and Educational Outcomes. Sociology of Education 71: 295-313.

Coleman, J.S., 1988: Social Capital in the Creation of Human Capital. American Journal of Sociology 94: S95.

Cooley, C.H., 1902: Human nature and the social order. New York: Charles Scribner's Sons.

Covington, M.V., 1984: The Self-Worth Theory of Achievement Motivation: Findings and Implications. The Elementary School Journal 85: 5-20.

Covington, M.V. \& R. Beery, 1976: Self-worth and school learning. New York: Holt, Rinehart \& Winston.

Demo, D.H. \& R.C. Savin-Williams, 1983: Early Adolescent Self-Esteem as a Function of Social Class: Rosenberg and Pearlin Revisited. American Journal of Sociology 88: 763-774.

Dickhäuser, O., 2006: Fähigkeitsselbstkonzepte: Entstehung, Auswirkung, Förderung. Zeitschrift für Pädagogische Psychologie 20: 5-8.

Dickhäuser, O., C. Schöne, B. Spinath \& J. Stiensmeier-Pelster, 2002: Die Skalen zum akademischen Selbstkonzept. Zeitschrift für Differentielle und Diagnostische Psychologie 23: 393-405.

Dickhäuser, O. \& J. Stiensmeier-Pelster, 2003: Die Bedeutung wahrgenommener Lehrereinschätzungen für das Fähigkeitsselbstkonzept von Jungen und Mädchen in der Grundschule. Psychologie in Erziehung und Unterricht 50: 182-190.

Epstein, J.L., 2011: School, family, and community partnerships. Preparing educators and improving schools. Boulder, CO: Westview Press.

Erikson, R. \& J. Jonsson (Hrsg.), 1996a: Can Education Be Equalized? The Swedish Case in Comparative Perspective. Boulder: Westview Press.

Erikson, R. \& J. Jonsson, 1996b: Explaining Class Inequality in Education: The Swedish Test Case. S. 13-33 in: R. Erikson \& J. Jonsson (Hrsg.), Can Education Be Equalized? The Swedish Case in Comparative Perspective. Boulder: Westview Press.

Esser, H., 2002a: Soziologie. Spezielle Grundlagen. Band 1: Situationslogik und Handeln. Frankfurt/Main, New York: Campus-Verlag.

Esser, H., 2002b: Soziologie. Spezielle Grundlagen. Band 4: Opportunitäten und Restriktionen. Frankfurt/Main, New York: Campus-Verlag.

Festinger, L., 1954: A theory of social comparison processes. Human relations 7: 117-140.

Festinger, L., 1962 [1957]: A theory of cognitive dissonance. Stanford, California: Stanford University Press.

Försterling, F. \& M.J. Binser, 2002: Depression, School Performance, and the Veridicality of Perceived Grades and Causal Attributions. Personality and Social Psychology Bulletin 28: 1441-1449.

Gambetta, D., 1987: Were they pushed or did they jump? Individual decision mechanisms in education. Cambridge, New York: Cambridge University Press.

Gecas, V., 1982: The Self-Concept. Annual Review of Sociology 8: 1-33.

Haaga, David A. F. \& A.T. Beck, 1995: Perspectives on depressive realism: Implications for cognitive theory of depression. Behaviour Research and Therapy 33: 41-48.

Helmke, A., 1992: Selbstvertrauen und schulische Leistung. Göttingen: Hogrefe.

Hofferth, S.L., J. Boisjoly \& G.J. Duncan, 1998: Parents' Extrafamilial Resources and Children's School Attainment. Sociology of Education 71: 246-268. 
Hyman, H.H., 1966: The value system of different classes in: S.M. Lipset \& R. Bendix (Hrsg.), Class, Status, and Power: Social Stratification in Comparative Perspective. London: Routledge \& Kegan Paul.

Jackson, M. (Hrsg.), 2013: Determined to Succeed? Performance Versus Choice in Educational Attainment. Palo Alto: Stanford University Press.

Kelley, H.H., 1973: The processes of causal attribution. American Psychologist 28: 107-128.

Kristen, C., 1999: Bildungsentscheidungen und Bildungsungleichheit - ein Überblick über den Forschungsstand. Mannheimer Zentrum für Europäische Sozialforschung (MZES).

Lareau, A., 1987: Social Class Differences in Family-School Relationships: The Importance of Cultural Capital. Sociology of Education 60: 73-85.

Lareau, A., 2011: Unequal childhoods. Class, race, and family life. Berkeley: University of California Press.

Lin, N., 2001: Social capital. A theory of social structure and action. Cambridge, New York: Cambridge University Press.

Lindenberg, S., 1984: Normen und die Allokation sozialer Wertschätzung. S. 169-191 in: D. Dörner \& H. Todt (Hrsg.), Normengeleitetes Verhalten in den Sozialwissenschaften. Berlin: Duncker \& Humblot.

Lockwood, D., 1981: The Weakest Link in the Chain? Some Comments on the Marxist Theory of Action. Research in the Sociology of Work 1: 435-481.

Marsh, H.W., 1986: Verbal and math self-concepts: An internal/external frame of refrence model. American Educational Research Journal 23: 129-149.

Mead, G.H., 1934: Mind, self, and society. Chicago: University of Chicago Press.

Ormel, J., S. Lindenberg, N. Steverink \& L.M. Verbrugge, 1999: Subjective well-being and social production functions. Social Indicators Research 46: 61-90.

Paulus, W. \& H.-P. Blossfeld, 2007: Schichtspezifische Präferenzen oder sozioökonomisches Entscheidungskalkül? Zur Rolle elterlicher Bildungsaspirationen im Entscheidungsprozess beim Übergang von der Grundschule in die Sekundarstufe. Zeitschrift für Pädagogik 53: 491-508.

Ream, R.K. \& G.J. Palardy, 2008: Reexamining Social Class Differences in the Availability and the Educational Utility of Parental Social Capital. American Educational Research Journal 45: 238273.

Relikowski, I., T. Schneider \& H.-P. Blossfeld, 2010: Primäre und sekundäre Herkunftseffekte beim Übergang in das gegliederte Schulsystem: Welche Rolle spielen soziale Klasse und Bildungsstatus in Familien mit Migrationshintergrund in: T. Beckers, K. Birkelbach, J. Hagenah \& U. Rosar (Hrsg.), Komparative empirische Sozialforschung. Wiesbaden: VS Verlag für Sozialwissenschaften.

Rheinberg, F., 2006: Bezugsnormorientierung. S. 55-62 in: D.H. Rost (Hrsg.), Handwörterbuch Pädagogische Psychologie. Weinheim: Beltz PVU.

Rosenberg, M. \& L.I. Pearlin, 1978: Social Class and Self-Esteem Among Children and Adults. American Journal of Sociology 84: 53-77.

Roth, T., Z. Salikutluk \& I. Kogan, 2010: Auf die "richtigen" Kontakte kommt es an! Soziale Ressourcen und die Bildungsaspiration der Mütter von Haupt-, Real- und Gesamtschülern in Deutschland. S. 179-212 in: B. Becker \& D. Reimer (Hrsg.), Vom Kindergarten bis zur Hochschule. Die Generierung von ethnischen und sozialen Disparitäten in der Bildungsbiographie. Wiesbaden: VS Verlag für Sozialwissenschaften.

Sayer, L.C., A.H. Gauthier \& F.F. Furstenberg, 2004: Educational differences in parents' time with children: Cross-national variations. Journal of Marriage and Family 66: 1152-1169.

Schilling, S.R., J.R. Sparfeldt \& D.H. Rost, 2006: Facetten schulischen Selbstkonzepts. Welchen Unterschied macht das Geschlecht? Zeitschrift für Pädagogische Psychologie 20: 9-18.

Sewell, W.H., A.O. Haller \& G.W. Ohlendorf, 1970: The educational and early occupational status attainment process: replication and revision. American Sociological Review 35: 1014-1027.

Shavelson, R.J., J.J. Hubner \& G.C. Stanton, 1976: Self-concept: Validation of construct interpretations. Review of Educational Research: 407-441. 
Stocké, V., H.-P. Blossfeld, K. Hoenig \& M. Sixt, 2011: Social inequality and educational decisions in the life course. Zeitschrift für Erziehungswissenschaft 14: 103-119.

Stryker, S., 2002 [1980]: Symbolic interactionism. A social structural version. Caldwell, N. J.: Blackburn Press.

Taylor, S.E. \& J.D. Brown, 1988: Illusion and well-being: A social psychological perspective on mental health. Psychological Bulletin 103: 193-210.

Turner, R.H., 1978: The Role and the Person. American Journal of Sociology 84: 1-23.

Twenge, J.M. \& W.K. Campbell, 2002: Self-Esteem and Socioeconomic Status: A Meta-Analytic Review. Personality and Social Psychology Review 6: 59-71.

Weiner, B., 1972: Theories of motivation: from mechanism to cognition. Chicago: Markham.

Weiner, B., 1974: Achievement motivation and attribution theory. Morristown, N. J.: General Learning Press.

Wohlkinger, F., H. Ditton, J. von Maurice, M. Haugwitz \& H.-P. Blossfeld, 2011: 10 Motivational concepts and personality aspects across the life course. Zeitschrift für Erziehungswissenschaft Special Issue 14: 155-168.

\section{Appendix}

\section{Complete regression table with parental education as measure of social origin}

\begin{tabular}{lcccc}
\hline & \multicolumn{2}{c}{ quasi-standardized } & \multicolumn{2}{c}{ quasi-standardized accuracy } \\
academic self-concept & of self-evaluation \\
\cline { 2 - 5 } & null model & model 1 & null model & model 2 \\
\hline \multirow{2}{*}{ standardized age } & -0.00497 & -0.00529 & -0.00847 & -0.00892 \\
& $(0.0080)$ & $(0.0080)$ & $(0.0081)$ & $(0.0081)$ \\
Female & $-0.147^{* * *}$ & $-0.148^{* * *}$ & $-0.147^{* * *}$ & $-0.148^{* * *}$ \\
Female * Quasi-standardized school & $(0.015)$ & $(0.014)$ & $(0.015)$ & $(0.014)$ \\
grades & $0.0627^{* * *}$ & $0.0641^{* * *}$ & $0.0616^{* * *}$ & $0.0627^{* * *}$ \\
Respondent parent female & $(0.018)$ & $(0.018)$ & $(0.018)$ & $(0.018)$ \\
& -0.0297 & -0.0303 & $-0.0346 \dagger$ & $-0.0348 \dagger$ \\
standardized household size & $(0.019)$ & $(0.019)$ & $(0.019)$ & $(0.019)$ \\
& -0.0110 & -0.0159 & -0.00402 & -0.00872 \\
standardized (Household size) & $(0.037)$ & $(0.036)$ & $(0.037)$ & $(0.037)$ \\
Both parents living in the household & 0.000351 & 0.000755 & -0.000126 & 0.000261 \\
& $(0.0029)$ & $(0.0028)$ & $(0.0029)$ & $(0.0028)$ \\
Migration background & -0.0152 & -0.0186 & -0.0216 & -0.0252 \\
& $(0.024)$ & $(0.024)$ & $(0.023)$ & $(0.023)$ \\
Hauptschule & 0.00691 & 0.00590 & 0.0193 & 0.0183 \\
& $(0.027)$ & $(0.027)$ & $(0.027)$ & $(0.027)$ \\
School with several courses of education & -0.0232 & -0.000390 & -0.0198 & 0.00307 \\
& $(0.020)$ & $(0.023)$ & $(0.020)$ & $(0.023)$ \\
Realschule & 0.00170 & 0.0179 & 0.00705 & 0.0242 \\
& $(0.027)$ & $(0.028)$ & $(0.027)$ & $(0.028)$ \\
Comprehensive school & -0.0106 & 0.00468 & -0.00287 & 0.0131 \\
Quasi-standardized school grades & $(0.014)$ & $(0.015)$ & $(0.015)$ & $(0.016)$ \\
Quasi-standardized (school grades) & 0.0176 & 0.0280 & 0.0192 & 0.0300 \\
Low education & $(0.021)$ & $(0.021)$ & $(0.020)$ & $(0.021)$ \\
& $0.444^{* * *}$ & $0.489 * * *$ & $-0.553^{* * *}$ & $-0.511^{* * *}$ \\
& $(0.015)$ & $(0.020)$ & $(0.015)$ & $(0.020)$ \\
& $0.0243^{*}$ & $0.0178+$ & $0.0266^{*}$ & $0.0205^{*}$ \\
& $(0.010)$ & $(0.010)$ & $(0.010)$ & $(0.010)$ \\
& & $-0.0637^{*}$ & & $-0.0636^{*}$ \\
& & & & \\
& & & & \\
& & & &
\end{tabular}




\begin{tabular}{|c|c|c|c|c|}
\hline \multirow{3}{*}{ Middle education } & \multicolumn{3}{|c|}{$(0.026)$} & $(0.025)$ \\
\hline & \multirow{2}{*}{\multicolumn{3}{|c|}{$\begin{array}{c}-0.0349+ \\
(0.018)\end{array}$}} & $-0.0390 *$ \\
\hline & & & & $(0.018)$ \\
\hline \multirow{2}{*}{$\begin{array}{l}\text { Low education * Quasi-standardized } \\
\text { school grades }\end{array}$} & \multicolumn{3}{|c|}{$-0.152 * * *$} & $-0.141 * * *$ \\
\hline & \multicolumn{3}{|c|}{$(0.030)$} & (0.029) \\
\hline \multirow{2}{*}{$\begin{array}{l}\text { Middle education * Quasi-standardized } \\
\text { school grades }\end{array}$} & \multirow{2}{*}{\multicolumn{3}{|c|}{$\begin{array}{c}-0.0459 * \\
(0.021)\end{array}$}} & $-0.0439 *$ \\
\hline & & & & $(0.021)$ \\
\hline \multirow{2}{*}{ Constant } & 0.103 & 0.119 & 0.117 & $0.135+$ \\
\hline & $(0.072)$ & $(0.072)$ & $(0.072)$ & $(0.072)$ \\
\hline$N$ & 5881 & 5881 & 5881 & 5881 \\
\hline$R^{2}$ & 0.324 & 0.328 & 0.392 & 0.395 \\
\hline $\bar{R}^{2}$ & 0.322 & 0.326 & 0.390 & 0.393 \\
\hline
\end{tabular}

\section{Complete regression table with parental social class as measure of social origin}

\begin{tabular}{|c|c|c|c|c|}
\hline & \multicolumn{2}{|c|}{$\begin{array}{l}\text { quasi-standardized } \\
\text { academic self-concept }\end{array}$} & \multicolumn{2}{|c|}{$\begin{array}{c}\text { quasi-standardized accuracy } \\
\text { of self-evaluation }\end{array}$} \\
\hline & null model & model 1 & null model & model 2 \\
\hline standardized age & $\begin{array}{l}-0.00459 \\
(0.0081)\end{array}$ & $\begin{array}{l}-0.00465 \\
(0.0081)\end{array}$ & $\begin{array}{l}-0.00795 \\
(0.0082)\end{array}$ & $\begin{array}{l}-0.00803 \\
(0.0082)\end{array}$ \\
\hline Female & $\begin{array}{c}-0.145^{* * *} \\
(0.014)\end{array}$ & $\begin{array}{c}-0.145^{* * *} \\
(0.014)\end{array}$ & $\begin{array}{c}-0.145^{* * *} \\
(0.015)\end{array}$ & $\begin{array}{c}-0.145^{* * *} \\
(0.015)\end{array}$ \\
\hline $\begin{array}{l}\text { Female * Quasi-standardized school } \\
\text { grades }\end{array}$ & $\begin{array}{c}0.0637 * * * \\
(0.019)\end{array}$ & $\begin{array}{c}0.0634^{* * *} \\
(0.019)\end{array}$ & $\begin{array}{c}0.0637 * * * \\
(0.018)\end{array}$ & $\begin{array}{c}0.0632 * * * \\
(0.018)\end{array}$ \\
\hline Respondent parent female & $\begin{array}{l}-0.0259 \\
(0.020)\end{array}$ & $\begin{array}{l}-0.0236 \\
(0.020)\end{array}$ & $\begin{array}{l}-0.0308 \\
(0.019)\end{array}$ & $\begin{array}{l}-0.0284 \\
(0.020)\end{array}$ \\
\hline standardized household size & $\begin{array}{l}-0.0192 \\
(0.037)\end{array}$ & $\begin{array}{l}-0.0214 \\
(0.037)\end{array}$ & $\begin{array}{r}-0.0119 \\
(0.037)\end{array}$ & $\begin{array}{r}-0.0135 \\
(0.037)\end{array}$ \\
\hline standardized (Household size) ${ }^{2}$ & $\begin{array}{l}0.000848 \\
(0.0029)\end{array}$ & $\begin{array}{l}0.000103 \\
(0.0029)\end{array}$ & $\begin{array}{l}0.000378 \\
(0.0029)\end{array}$ & $\begin{array}{l}0.000522 \\
(0.0029)\end{array}$ \\
\hline Both parents living in the household & $\begin{array}{l}-0.0112 \\
(0.025)\end{array}$ & $\begin{array}{r}-0.0144 \\
(0.025)\end{array}$ & $\begin{array}{r}-0.0193 \\
(0.024)\end{array}$ & $\begin{array}{l}-0.0219 \\
(0.024)\end{array}$ \\
\hline Migration background & $\begin{array}{c}0.00870 \\
(0.028)\end{array}$ & $\begin{array}{l}0.00906 \\
(0.028)\end{array}$ & $\begin{array}{l}0.0216 \\
(0.028)\end{array}$ & $\begin{array}{l}0.0219 \\
(0.027)\end{array}$ \\
\hline Hauptschule & $\begin{array}{l}-0.0252 \\
(0.021)\end{array}$ & $\begin{array}{l}-0.0145 \\
(0.022)\end{array}$ & $\begin{array}{l}-0.0226 \\
(0.020)\end{array}$ & $\begin{array}{l}-0.0139 \\
(0.021)\end{array}$ \\
\hline School with several courses of education & $\begin{array}{c}0.00164 \\
(0.027)\end{array}$ & $\begin{array}{l}0.0121 \\
(0.027)\end{array}$ & $\begin{array}{c}0.00722 \\
(0.027)\end{array}$ & $\begin{array}{l}0.0156 \\
(0.027)\end{array}$ \\
\hline Realschule & $\begin{array}{c}-0.0106 \\
(0.014)\end{array}$ & $\begin{array}{c}-0.00346 \\
(0.014)\end{array}$ & $\begin{array}{c}-0.00336 \\
(0.015)\end{array}$ & $\begin{array}{c}-0.00279 \\
(0.015)\end{array}$ \\
\hline Comprehensive school & $\begin{array}{l}0.0263 \\
(0.020)\end{array}$ & $\begin{array}{l}0.0304 \\
(0.020)\end{array}$ & $\begin{array}{l}0.0288 \\
(0.020)\end{array}$ & $\begin{array}{c}0.0324 \dagger \\
(0.020)\end{array}$ \\
\hline Quasi-standardized school grades & $\begin{array}{c}0.445^{* * *} \\
(0.015)\end{array}$ & $\begin{array}{c}0.463 * * * \\
(0.017)\end{array}$ & $\begin{array}{c}-0.551^{* * *} \\
(0.015)\end{array}$ & $\begin{array}{c}-0.535^{* * *} \\
(0.017)\end{array}$ \\
\hline Quasi-standardized (school grades) ${ }^{2}$ & $\begin{array}{c}0.0224^{*} \\
(0.011)\end{array}$ & $\begin{array}{c}0.0192+ \\
(0.011)\end{array}$ & $\begin{array}{c}0.0246^{*} \\
(0.010)\end{array}$ & $\begin{array}{c}0.0220^{*} \\
(0.010)\end{array}$ \\
\hline Working class & & $\begin{array}{r}-0.0150 \\
(0.029)\end{array}$ & & $\begin{array}{c}-0.00825 \\
(0.029)\end{array}$ \\
\hline
\end{tabular}




\begin{tabular}{|c|c|c|c|c|}
\hline Intermediate class & \multicolumn{3}{|c|}{$-0.0350 *$} & $\begin{array}{c}-0.0309+ \\
(0.017)\end{array}$ \\
\hline \multirow{2}{*}{$\begin{array}{l}\text { Working class * Quasi-standardized } \\
\text { school grades }\end{array}$} & & $-0.0684 \dagger$ & & -0.0524 \\
\hline & & (0.037) & & (0.035) \\
\hline \multirow{2}{*}{$\begin{array}{l}\text { Intermediate class * Quasi-standardized } \\
\text { school grades }\end{array}$} & & $-0.0391 \dagger$ & & $-0.0376+$ \\
\hline & & $(0.022)$ & & $(0.022)$ \\
\hline \multirow{2}{*}{ Constant } & 0.0845 & 0.0904 & 0.100 & 0.105 \\
\hline & $(0.072)$ & $(0.072)$ & $(0.072)$ & $(0.072)$ \\
\hline$N$ & 5767 & 5767 & 5767 & 5767 \\
\hline$R^{2}$ & 0.326 & 0.328 & 0.391 & 0.392 \\
\hline $\bar{R}^{2}$ & 0.325 & 0.326 & 0.389 & 0.390 \\
\hline
\end{tabular}

3. Central tendency and statistical dispersion of the most important variables

\begin{tabular}{|c|c|c|c|c|c|}
\hline & $\varnothing$ & SD & Min & Max & $\mathrm{N}$ \\
\hline \multicolumn{6}{|l|}{ Academic self-concept } \\
\hline German & 2.936 & 0.620 & 1 & 4 & 7988 \\
\hline standardized & 0.010 & 0.983 & -3.145 & 2.759 & 7988 \\
\hline Mathematics & 2.541 & 0.928 & 1 & 4 & 7949 \\
\hline standardized & 0.001 & 0.990 & -2.448 & 2.517 & 7949 \\
\hline $\begin{array}{l}\text { German + Mathematics averaged } \\
\text { standardized }\end{array}$ & 2.738 & 0.548 & 1 & 4 & 8104 \\
\hline - overall & 0.004 & 0.680 & -2.420 & 2.106 & 8104 \\
\hline - $\quad$ low parental education & -0.068 & 0.663 & -2.420 & 2.002 & 1533 \\
\hline - $\quad$ high parental education & 0.102 & 0.695 & -2.060 & 2.032 & 2182 \\
\hline \multicolumn{6}{|l|}{ School grades } \\
\hline German & 2.833 & 0.830 & 1 & 6 & 7403 \\
\hline standardized & -0.000 & 0.983 & -4.093 & 2.837 & 7403 \\
\hline Mathematics & 2.928 & 1.028 & 1 & 6 & 7364 \\
\hline standardized & -0.008 & 0.987 & -2.989 & 2.690 & 7364 \\
\hline $\begin{array}{l}\text { German + Mathematics averaged } \\
\text { standardized }\end{array}$ & 2.880 & 0.777 & 1 & 6 & 7422 \\
\hline - overall & -0.005 & 0.814 & -3.540 & 2.446 & 7422 \\
\hline - low parental education & -0.139 & 0.807 & -2.361 & 2.282 & 1396 \\
\hline - $\quad$ high parental education & 0.136 & 0.829 & -3.200 & 2.446 & 1984 \\
\hline Accuracy of self-evaluation & 0.015 & 0.708 & -3.622 & 3.348 & 7388 \\
\hline
\end{tabular}

Table 5: Central tendency and statistical dispersion of the variables academic self-concept, school grades and the accuracy of self-evaluation. Regarding academic self-concept and school grades, the key figures are exhibited for each domain (German and Mathematics) separately as well as their arithmetical average. This information is shown both in the original scale and in the standardized form. 
4. Key figures of the cross tabulation: (categorized) self-evaluation $x$ parental education

\begin{tabular}{lccccc}
\hline Chance (Odds) of ... & \multicolumn{2}{c}{ parental education } & Odds Ratio & p-Wert & Cramérs V \\
\hline underestimation & & & & & \\
50\% within accuracy & 0.27 & 0.33 & 0.83 & 0.004 & 0.0567 \\
95\% within accuracy & 0.02 & 0.01 & 1.28 & 0.011 & 0.0515 \\
accurate self-evaluation & & & & & \\
50\% within accuracy & 1.09 & 1.15 & 0.95 & 0.004 & 0.0567 \\
95\% within accuracy & 21.42 & 35.63 & 0.60 & 0.011 & 0.0515 \\
overestimation & & & & & \\
50\% within accuracy & 0.36 & 0.28 & 1.28 & 0.004 & 0.0567 \\
95\% within accuracy & 0.03 & 0.01 & 2.06 & 0.011 & 0.0515 \\
\hline
\end{tabular}

Table 6: Key figures of the cross tabulation: (categorized) self-evaluation $x$ parental education. Exhibited are odds, odds ratios as well as p-values and Cramer's V of the $\chi^{2}$-test.

\section{Declaration of authorship}

I hereby declare that the thesis submitted is my own unaided work. All direct or indirect sources used are acknowledged as references. I am aware that the thesis in digital form can be examined for the use of unauthorized aid and in order to determine whether the thesis as a whole or parts incorporated in it may be deemed as plagiarism. For the comparison of my work with existing sources I agree that it shall be entered in a database where it shall also remain after examination, to enable comparison with future theses submitted. Further rights of reproduction and usage, however, are not granted here. This paper was not previously presented to another examination board and has not yet been published.

Mannheim, den 01.02.2014 